3,9 przez „wielbimy”. Jest to też świadectwo, że tłumaczenie słów brk/eulogein nie od dziś związane jest $\mathrm{z}$ poważnymi trudnościami i rozterkami.

Wysuwane tu propozycje miałyby większy sens, gdyby w polskich tłumaczeniach Biblii, zwłaszcza Psałterza, bardziej uzgodnić terminologię pochwalną. W BT np. słowo „uwielbić” oddaje przynajmniej sześć czasowników hebrajskich: rum (Wj 15,2), šhh (Ps 29;2; 95,6), gdl (Ps 34,4); jdh (Ps 7,18), kbd (Ps 50,15) i hll (Ps 56,5.11). Imiesłów „uwielbiony” jest odpowiednikiem trzech słów: baruk (Wj 18,10; Ezd 7,27), kbd (Ez 28,22) i qdsz (Ez 28,25). Są to; co prawda, synonimy, ale większa jednoznaczność i konsekwencja $\mathrm{w}$ tłumaczeniu wydaje się $\mathrm{z}$ wielu względów potrzebna. Podobnie skomplikowana jest sytuacja ze słowem „wysławiać". Dalsze porównania wykraczałyby jednak poza zakres tego opracowania.

Oltarzew

Ks. JULIAN WARZECHA SAC

SPRAWOZDANIA I WIADOMOŚ I

\title{
SPRAWOZDANIE PREZESA POLSKIEGO TOWARZYSTWA TEOLOGICZNEGO W KRAKOWIE ZA ROK 1996
}

\section{STAN TOWARZYSTWA}

1.1. Z końcem roku 1996 Polskie Towarzystwo Teologiczne w Krakowie liczyło 392 członków. W roku sprawozdawczym przyjęto 9 nowych członków.

W ostatnich miesiącach odeszli do wieczności:

- mgr Wiktor Zębaty (wieloletni skarbnik PTT)

- ks. kan. mgr Wacław Heczko (członek Komisji Kontrolującej w poprzednim zarządzie)

1.2. Poprzednie Walne Zebranie Polskiego Towarzystwa Teologicznego w Krakowie miało miejsce 14 lutego 1996 r. i dokonało wyboru nowych władz Towarzystwa na okres trzech lat.

Ukonstytuowany wówczas Zarząd Towarzystwa działal w roku sprawozdawczym w następującym składzie: 
1.2.1. Zarząd:

Prezes: ks. dr Kazimierz Panuś

Wiceprezes: o. dr Józef Marecki OFM Cap

Sekretarz: ks. mgr Kazimierz Moskała baty

Skarbnik: tymczasowo do chwili powołania nowego p. mgr Wiktor Zę-

od września 1996 - ks. mgr Andrzej Mójżeszko

Bibliotekarz: ks. dr Jan Bednarczyk

Kierownik Sekcji Wydawniczej: ks. doc. dr hab. Stefan Koperek CR

1.2.2. Komisja kontrolująca:

Przewodniczący: ks. dr Kazimierz Waliczek

Członkowie: ks. doc. dr hab. Jan Wal

ks. lic. Czesław Świniarski

1.2.3. Sąd koleżeński:

Przewodniczący: ks. inf. dr Stefan Cichy

Członkowie: ks. doc. dr hab. Jerzy Chmiel

o. dr hab. Jan Mazur OSPPE

\subsection{ZEBRANIA ZARZĄDU}

Spełniając wymogi statutowe Zarząd odbył w roku sprawozdawczym. 4 zebrania:

7 kwietnia 1996, 19 czerwca 1996, 4 grudnia 1996 i 18 lutego 1997 r.

Na pierwszym spotkaniu zatwierdzono kierowników sekcji za wyjątkiem sekcji filozoficznej i dogmatycznej, których stanowiska wakowały. Na zebraniu tym p. mgr Wiktor Zębaty zrezygnował $\mathrm{z}$ funkcji skarbnika $\mathrm{z}$ powodu nasilającej się choroby. Zarząd zaakceptował plan komputerowego opracowania bazy danych Polskiego Towarzystwa Teologicznego w Krakowie w oparciu o program Microsoft Access. Podjęto także decyzję powołania Sekcji Teologii Życia Wewnętrznego oraz przyjęto nowych członków.

$\mathrm{Na}$ drugim zebraniu została zaprezentowana komputerowa lista członków PTT w Krakowie. Dzięki temu po raz pierwszy dysponujemy w miarę aktualną informacją dotycząca naszego Towarzystwa. Umożliwia to m.in. szybkie i sprawne prowadzenie korespondencji, co mogli Wielce Szanowni Członkowie Towarzystwa zauważyć otrzymując okolicznościowe życzenia wielkanocne i bożonarodzeniowe oraz chociażby zaproszenie na dzisiejsze walne zebranie. Wspomniana wyżej baza danych zrobiona w oparciu o program Microsoft Access jest systematycznie uzupełniana. W ramach zebrania przyjęto także nowych członków.

$\mathrm{Na}$ trzecim zebraniu zarząd powołał ks. mgra Andrzeja Mojżeszkę na skarbnika PTT. Omówione zostały planowane pod patronatem PTT sympozja (Akcja Katolicka zadaniem dla świeckich - Sekcja SocjologicznoPastoralna, Felix Saeculum Cracoviae - Sekcja Historyczna). Zastanawiano się nad problemem upowszechnienia wiedzy o PTT w środkach masowego przekazu. Zarząd zwrócil się z prośbą o powolanie o. Mariana Sojki CSsR na rzecznika prasowego Towarzystwa. Sporo uwagi poświęcono przy- 
gotowaniu Walnego Zebrania, które w dużej mierze poświęcone zostanie uczczeniu złotego jubileuszu czasopisma „Ruch Biblijny i Liturgiczny” wydawanego przez Sekcję Biblijno-Liturgiczną PTT w Krakowie. Zebrani wysłuchali cennych informacji ks. doc. dra hab. Jerzego Chmiela nt. form upamiętnienia tego ważnego wydarzenia jak również na temat poszerzenia komitetu redakcyjnego o nowe osoby. Obecny na zebraniu ks. inf. dr Stefan Cichy wyrazil zgodę na współredagowanie pisma. Ks. doc. dr hab. Jerzy Chmiel przedstawił również dzieje Studium Syndonologicznego, które zostało powolane przed 15 laty uchwała Zarządu PTT w Krakowie i nadal rozwija swą działalność [szczególowe informacje na ten temat zostały opublikowane w numerze 3 (1996) RBL]. Postanowiono także kontynuować dalsze rozmowy nt. zbliżenia do PTT w Krakowie wrocławskiego Towarzystwa Teologicznego.

Zebranie czwarte odbyło się w dniu 1802 1997. Jego problematykę zdominowało omówienie form uczczenia złotego jubileuszu czasopisma „Ruch Biblijny i Liturgiczny” i aktualnego Walnego Zebrania. Postanowiono uhonorować medalami i dyplomami Towarzystwa dwie osoby: ks. doc. Jerzego Chmiela (red. naczelny RBL) i o. Franciszka Małaczyńskiego OSB (wieloletni członek redakcji RBL). Na prośbę Kurii Metropolitalnej w Częstochowie podjęto uchwałę o utworzeniu nowej sekcji terenowej w Częstochowie. Sprawą tą z polecenia Ordynariusza zajmuje się ks. dr Teofil Siudy. Zarząd zwróci się do ks. dra D. Oko i ks. A. Olszewskiego z prośbą o podjęcie się zadania kierowników wakujących sekcji dogmatycznej i filozoficznej.

\section{DZIAŁALNOŚĆ TOWARZYSTWA}

2.1. W ramach PTT $w$ Krakowie dziala nominalnie 12 sekcji specjalistycznych i 6 sekcji terenowych, przy czym sekcje filozofczna i dogmatyczna faktycznie zawiesiły swoją działalność. PTT w Krakowie ma także własną Sekcję Wydawniczą w postaci wydawnictwa „Unum”.

2.1.1. Sekcja Biblijna. Przewodniczący - ks. prof. dr hab. Tomasz Jelonek. Sekcja w tym roku nie organizowała spotkań.

2.1.2. Sekcja Apologetyczno-Religioznawcza. Kierownikiem sekcji jest ks. dr Tadeusz Dzidek. Sekcja nie zorganizowała w 1996 żadnego formalnego spotkania. Miały natomiast miejsce spotkania nieformalne członków sekcji, których celem była konsultacja i współredakcja podręcznika pt. Teologia fundamentalna. Ich owocem jest oddany do druku pierwszy z pięciu tomów pt. Człowiek-filozofia-Bóg. Tomy następne są w przygotowaniu.

2.1.3. Sekcja Historyczna. Jej pracami kieruje ks. dr Andrzej Bruździński. Sekcja podejmowała szereg inicjatyw. Jednak nie zostało złożone sprawozdanie i księga sekcyjna.

2.1.4. Sekcja Homiletyczna. Przewodniczącym sekcji jest ks. dr Kazimierz Panuś.

W roku sprawozdawczym 1996 sekcja homiletyczna spotkała się trzykrotnie. Było to w ramach:

1. spotkania wykładowców homiletyki (23 II 1996, w budynku Wyższego Seminarium Duchownego Księży Misjonarzy przy ul. Stadom 4). 
W spotkaniu wzięło udział 10 profesorów z Krakowa, Tuchowa i Stadnik. Podkreślono doniosłą rolę dla rozwoju polskiej homiletyki serii wydawniczej Redemptoris Missio, której przewodzi o. dr Wiesław Przyczyna. Redaktor tej serii - obecny na spotkaniu - zaprezentował plany wydawnicze na rok 1996. Ze szczególnym odzewem spotkały się wydane w tej serii „Rekolekcje dla dzieci”.

2. warsztatów homiletycznych (30-31 V).

Członkowie sekcji wzięli udzial w majowych warsztatach homiletycznych, które prowadził o. James A. Wallace (USA).

3 . IV sympozjum homiletycznego (24-25 X) w Wyższym Seminarium Diecezji Sosnowieckiej.

Sympozjum podjęło zagadnienie słuchacza słowa Bożego. W trakcie obrad podjęto problem przygotowania akademickiego podręcznika $\mathrm{z}$ historii kaznodziejstwa. Pracami tymi kieruje kierownik Sekcji Homiletycznej.

2.1.5. Sekcja Liturgiczna. Sekcję prowadzi ks. dr Stanisław Szczepaniec. Sekcja w tym roku nie organizowała spotkań.

2.1.6. Sekcja Misjologiczna. Kierownikiem sekcji jest ks. dr Marian Pawlos CM. W roku sprawozdawczym Sekcja opracowała referat pt. Pojęcie inkulturacji w posynodalnej adhortacji Jana Pawla II "Ecclesia in Africa", a rozumienie tego terminu w świetle Regut, Konstytucji $i$ zwyczajów Zgromadzenia Misji. Referat ten został wygłoszony na sympozjum z okazji 300-lecia kościoła Św. Krzyża w Warszawie. Członkowie sekcji wzięli także udział w spotkaniu poświęconym misjom w Indiach, jakie miało miejsce w Kurii Metropolitalnej 13 grudnia ub. $\mathbf{r}$.

2.1.7. Sekcja Prawa Kanonicznego. Kierownikiem sekcji jest ks. dr Józef Rapacz.

2.1.8. Sekcja Teologii Moralnej. Sekcję prowadzi ks. dr Kazimierz Kaczmarczyk. W roku sprawozdawczym sekcja zorganizowała jedno spotkanie, w ramach którego ks. prof. dr hab. Krzysztof Szczygiel wyglosił referat Problemy bioetyczne $w$ spoleczeństwie pluralistycznym.

2.1.9. Sekcja Socjologiczno-Pastoralna. Pracami sekcji kieruje ks. dr Stefan Dobrzanowski. Skupia ona ok. 20 członków, głównie wykładowców teologii pastoralnej i katolickiej nauki społecznej. W dniu 14 grudnia w gmachu OO. Franciszkanów Sekcja zorganizowała sympozjum nt. Akcji Katolickiej. Wzięło w nim udział dwóch biskupów i liczni świeccy i duchowni co wskazuje na aktualność podjętej problematyki. W sumie wygłoszono 8 wykładów - niektóre $\mathrm{z}$ nich miały charakter komunikatów.

2.1.10. Sekcja Sztuki Sakralnej. Kierownikiem sekcji jest ks. dr Zdzisław Kliś.

Sekcja zorganizowała w dniu 15. 11. drugą już sesję poświęconą odnawianemu kościołowi Św. Krzyża w Krakowie. W jej ramach wygłoszono 11 referatów, w tym takich znakomitych znawców sztuki jak p. prof. dr hab. Jan Samek i p. prof. dr hab. Jerzy Gadomski. Te i inne artykuły zostały złożone do druku i ukażą się jako drugi tom Studia do dziejów kościoła Św. Krzyża wrakowie.

2.1.2. Sekcja Dogmatyczna i Filozoficzna - praktycznie nie funkcjonowała w roku sprawozdawczym, gdyż mimo usilnych zabiegów nie udało się Zarządowi znaleźć kierowników sekcji. 
2.2. Polskie Towarzystwo Teologiczne $w$ Krakowie działa także poprzez swoje sekcje terenowe. I tak:

2.2.1. Sekcja Terenowa w Katowicach. Prace sekcji koordynuje ks. dr Antoni Reginek. W roku sprawozdawczym sekcja odbyła dwa zebrania połączone $\mathrm{z}$ wykładami i dyskusją. Podczas pierwszego spotkania, które miało miejsce dnia 23 maja w Piekarach Śl. zostały wygłoszone prelekcje związane z muzyką sakralną. Ks. doc. dr hab. Janusz Wycisło, dziekan Wydz. Hist. PAT mówił na temat Geneza i rozwój ilościowy pieśni piekarskich (od XVII w. do czasów wspótczesnych) a ks. dr Antoni Reginek omówił Najstarsze śpiewy liturgiczne w języku ojczystym na Ślqsku. W spotkaniu wzięli też udział członkowie Oddziału Sląskiego Polskiego Związku Chórów i Orkiestr.

Kolejne zebranie Sekcji katowickiej mialo miejsce 25 listopada. Podczas tego spotkania ks. prałat dr Jerzy Pawlik wygłosil wykład na temat Język ojczysty jako droga do tożsamości. Zebranie miało miejsce w Wyższym Seminarium Duchownym w Katowicach, a obok czlonków katowickiej Sekcji PTT wzięło w nich także udział liczne grono studentów teologii. Członkowie PTT Sekcji w Katowicach brali też czynny udział w zorganizowaniu w łączności z Górnośląskim Międzyuczelnianym Tow. Akademickim „Universitas” sympozjum naukowego w Wyższym Śląskim Seminarium Duchownym na temat Piękno zagrożone. Sympozjum miało miejsce 6 i 7 listopada 1996.

2.2.2. Sekcja Terenowa w Kalwarii Zebrzydowsikiej. Sekcją kieruje o. dr Romuald Kośla. W roku sprawozdawczym sekcja odbyła siedem spotkań, w tym jedno sympozjum i jedno spotkanie o charakterze dokształcającym dla najmłodszych kapłanów. W ramach zebrań referaty wygłaszali p. prof. Teresa Kukułowicz, o. prof. Luigi Padovese OFMCap, ks. prof. dr hab. Ignacy Dec oraz profesorowie Wyższego Serninarium OO. Bernardynów. W dniach 10 i 11 IX 1996 sekcja zorganizowala sympozjum naukowe z okazji XXV-lecia pracy bernardyńskich misjonarzy w Zairze.

2.2.3. Sekcja Terenowa w Przemyślu. Pracami sekcji kieruje ks. dr hab. Marian Wolicki. W roku sprawozdawczym sekcja odbyła pięć spotkań z referatami ks. dra Romana Wawry, ks. dra Mariana Rojka (trzykrotnie) i ks. dra Tadeusza Śliwy. Z racji wyznaczonej na dzień dzisiejszy sesji pedagogicznej z ks. abpem kierownik sekcji przeprasza, iż nie może przybyć.

2.2.4. Sekcja Terenowa w Tarnowie. Przewodniczącym sekcji od 18 października ub. r. jest ks. dr Zbigniew Wolak. Sekcja odbyła trzy zebrania. Na pierwszym (12 11 1996) omawiano praktyczne aspekty kultu Eucharystii w seminariach duchownych i parafiach. Podstawę dyskusji stanowił wykład ks. dr B. Margańskiego Formacja eucharystyczna alumnów. W dniu 10121996 zebranie rozpoczęło się referatem ks. dra W. Szczebaka nt. Józef Baba - twórca muzealnictwa w Polsce. Dyskusja toczyła się wokól estetycznych i wychowawczych aspektów sztuki religijnej oraz wspólczesnych problemów związanych $z$ wystrojem obiektów sakralnych. Kolejne zebranie otwarl referat ks. dr Z. Wolaka Logika w gloszeniu wiary. W dyskusji zwrócono uwagę na ograniczenia stosowalności logiki do teologii oraz na możliwości wykorzystania analiz logicznych języków potocznych (filozofowie). Omówiono także problemy związane z przygotowaniem sesji naukowych w roku 1997, w szczególności sympozjum z cyklu Nauka i wiara, które odbędzie się w kwietniu. 
2.2.4. Sekcja Terenowa w Tuchowie. Kierownik sekcji o. dr Stanisław Bafia CSsR. Sekcja nie przedstawiła sprawozdania ze swej działalności.

2.2.5. Sekcja Terenowa w Rzeszowie. Kierownik sekcji ks. dr Stanisław Nabywaniec. Sekcja ta znajduje się wciąż w stanie organizacji. Zarząd nie dysponuje danymi o jej działalności.

\section{UWAGI KOŃCOWE}

Sprawozdanie z działalności skarbnika oraz Sekcji Wydawniczej PTT w Krakowie zostanie złożone oddzielnie.

Podsumowując dzialalność Zarządu na przestrzeni ostatniego roku za swoisty sukces należy uznać komputerowe opracowanie składu osobowego PTT w Krakowie, nawiązanie bliższych kontaktów z Wrocławiem i innymi towarzystwami. Czynione są także wysiłki na rzecz szerokiej informacji o Towarzystwie w mediach.

Natomiast na przestrzeni ostatniego roku nie udało się Zarządowi ożywić działalności niektórych sekcji. Organizowanie spotkań sekcyjnych w większości wypadków nie spotykało się z szerokim odzewem i spotkania te gromadziły zwykle od kilku do kilkunastu osób. Chlubnym wyjątkiem są prace Sekcji Socjologiczno-Pastoralnej, Historycznej, Historii Sztuki i Homiletycznej. Sympozja organizowane przez te sekcje miały duże audytorium i stanowiły znaczące wydarzenie odnotowywane przez prasę. Dorobek tych sekcji ukaże się w osobnych publikacjach zbierających wygłoszone wtedy referaty.

Zarząd pragnie wyrazić szczerą wdzięczność wszystkim aktywnym członkom Towarzystwa, którzy mimo wielorakich trudności i przeszkód czynią wszystko, aby działalność Towarzystwa była kontynuowana i służyla dalszemu ubogaceniu polskiej myśli teologicznej.

Kraków

KS. KAZIMIERZ PANUŚ

\section{Ks. Jerzy Chmiel}

\section{DAWID W BIBLII. XVII KONGRES ACFEB, LILLE 1997}

W dniach 1-5 września 1997 r. w Uniwersytecie Katolickim w Lille miał miejsce XVII Kongres Association Catholique Française pour l'Etude de la Bible (= ACFEB) na temat: „Figures de David à travers la Bible” (co należałoby przetłumaczyć: Wyobrażenia Dawida poprzez Biblię). ACFEB 